\title{
Influences of Different Concentrations of Herbicides on the Growth and Yield of Maize as well as their Effects on the Associated Weeds in North-Western Nigeria
}

\author{
Bawale Sani Halliru ${ }^{1}$, Mahmoud Dogara Abdulrahman ${ }^{2 *}$, Saber W. Hamad ${ }^{2 \& 3}$, Nura Wada ${ }^{4}$, Tahir \\ Lawan Dalorimaand ${ }^{5}$, Bashir Ladan Aliero ${ }^{6}$ \\ ${ }^{1}$ Department of Biological Sciences. Al-Qalam University, Katsina, Nigeria \\ ${ }^{2}$ Department of Biology, Faculty of Education, Tishk International University, Erbil, Kurdistan Region, Iraq \\ ${ }^{3}$ Department of Field Crops Production, College of Agricultural Engineering Sciences, Salahaddin University, Erbil, Kurdistan Region, Iraq \\ ${ }^{4}$ Department of Science Laboratory Technology, Al-Qalam University, Katsina, Nigeria \\ ${ }^{5}$ Department of Agricultural Technology, Ramat Polytechnic, Maiduguri, Nigeria \\ ${ }^{6}$ Department of Plant Sciences, Usmanu Danfodiyo University Sokoto, Nigeria
}

Received 06 October 2021; revised 25 December 2021;

accepted 02 January 2022; available online 10 January 2022

doi: $10.24271 /$ psr. 38

\begin{abstract}
The field experiment was conducted in the dry season between December 2012 to April 2013 at Bakori, Bakori local government, Katsina $\left(11^{0} 33^{\prime} \mathrm{N}, 7^{0} 36^{\prime} \mathrm{E}\right)$. The experiment consisted of 8 treatments levels which include 4 different formulations each; viz: ParaeForce ${ }^{(R)}$ at $150 \mathrm{ml} / 20 \mathrm{~L}$ and $200 \mathrm{ml} / 20 \mathrm{~L}$, AminoForce $^{(\mathrm{R})}$ at $100 \mathrm{~mL} / 15 \mathrm{~L}$ and $125 \mathrm{~mL} / 15 \mathrm{~L}$ applied a day before sowing and 4 weeks after sowing and a weedy control. The treatments were laid out in randomized complete block design (RCBD). The objective was to evaluate resistant weeds to herbicides (ParaeForce ${ }^{(R)}$ and AminoForce ${ }^{(R)}$ ) and their effects on the growth and yield of maize. Result shows that 17 weed species from 11 families were encountered which include Cynodon dactylon, Cyperus rotundus, Doctylocterium aegyptium and Eleusine indica that shows signifcant $(\geq 0.05)$ resistance to ParaeForce ${ }^{(\mathrm{R})}+$ AminoForce ${ }^{(\mathrm{R})}$ at $150 \mathrm{~mL} /$ 20L followed by $100 \mathrm{~mL} / 15 \mathrm{~L}$ had $91.70,87.12$ and $49.15 \%$ weed control efficiencies at 4,8 and 16WAS. Sequential application of ParaeForce ${ }^{(R)}+$ AminoForce $^{(R)}$ at $200 \mathrm{ml} / 20 \mathrm{~L}$ followed by $125 \mathrm{~mL} / 15 \mathrm{~L}$ recorded significantly $(\geq 0.05)$ high maize yield of $(6.7 \mathrm{~kg})$ in all the three blocks and effective weed control with $86.28,77.58$ and $33.55 \%$ weed control efficiencies at 4,8 and 16 WAS. This study recommended the application of ParaeForce ${ }^{(\mathrm{R})}$ and AminoForce ${ }^{(\mathrm{R})}$ at $200 \mathrm{~mL} / 20 \mathrm{~L}$ followed by $125 \mathrm{~mL} / 15 \mathrm{~L}$ as an alternative way of reducing weed resistance to ParaeForce ${ }^{(\mathrm{R})}+$ AminoForce $^{(\mathrm{R})}$ formulation and to improved performance of maize yield in the experimental site.
\end{abstract}

(C) 2022 Production by the University of Garmian. This is an open access article under the LICENSE

https://creativecommons.org/licenses/by-nc/4.0/

Keywords: Herbicides, Weeds, Resistance, Maize

\section{Introduction}

A weed is a plant that is out of place, or it can be described generally as any undesired plant. Weeds are plants that are usually disliked by farmers and gardeners. They may also affect crop quality and make harvesting more difficult; crops produced in weedy conditions will generate lower yields or may not produce at all [1]. Even though the use of pesticides for weed control is a source of public concern and criticism nowadays [1]. Most naturalists and environmentalists oppose their use and other

* Corresponding author

E-mail address: abdulrahman.mahmud@tiu.edu.iq (Instructor).

Peer-reviewed under the responsibility of the University of Garmian. pesticides, instead advocating for alternative weed control methods or natural eco-friendly chemicals; however, synthetic herbicides are still widely used, considered for weed control, and heavily applied in developed and developing countries [2]. Chemical weed control is not commonly used in underdeveloped nations due to low labour costs, high chemical prices, and a lack of technical training and experience in herbicide administration [3]. These limitations lead in most cases to the misuse of the chemicals, crop injury and weeds resistance to herbicides [4]. Herbicide failure in the field can be caused by a variety of circumstances, the most common of which are human errors that result in inappropriate application methods [5]. Weed species resistance to herbicides is one of the most serious problems affecting the use of herbicides as one of the control agent of weeds [6]. Herbicides are still the most effective weed 
management method on the planet. As a result, the widespread evolution of herbicide resistance in weed populations inside intensive crop production systems poses a serious danger to cropping systems' long-term viability and profitability. Weeds are often great at surviving and reproducing in disturbed environments, and they are frequently the first species to colonize and dominate in these conditions [7]. Herbicide-resistant weeds may be controlled through cultural strategies including crop rotation and integrated weed management (IWM). With its unique mode of action, paraquat is one of the few chemical choices for preventing and mitigating issues with weeds that have developed resistance to the frequently used non-selective herbicides [8]. Weed control is a major problem to crop production. Studies have been done on weed management strategies in crops production which include cultural, mechanical and chemical methods [9]. Weed resistance stunts plant growth by competing for water, nutrients, and light with the crop [10]. Crop yields are particularly affected when either water or nutrients are scarce, making competition for these resources extremely fierce. The amount of light competition is determined by the canopy structure of the crop and the weed, as well as their relative establishment timeframes [11]. A tall-growing plant in a prostrate crop, such as goat weed in melon, is more likely than a prostrate weed in a tall crop, such as Portulaca in maize, to compete for light [12]. According to [13] the pre-dominant weed flora at slinking stage of maize crop during rainy season were mainly of Cyperus rotundus, Eleusine indica, Digitaria sanguinalis and Doctylocterium aegyptium. [14] reported that presence of 75 weed species in maize crop fields in Punjab and the predominant weeds associated with the crop were Eleusine aegyptium, Eragrostis tenella, Leptochloa panacea, Trianthema portulocastrum, Digera arvensis and Cyperus rotundus. [15] observed that the dominant weeds spp. in maize were,
Echinochloa colonum, Bracharia ramosa, Digitaria sanguinalis, Doctylocterium aegyptium, Eleusine indica, Setaria glauca, Sorghum halepense and Panicum spp. among the grassy weeds, Ageratum conyzoides, Galinoga parviflora, Commelina benghalensis, Lindernia ciliate, Polygonum hydropiper, Euphorbia geniculate and Oxalis latifolia among the broad leaved weeds and Cyperus rotundus among sedges. AminoForce are known to be effectives on selectives weeds like Achyranthes aspera, Boerhavia diffusa, Boerhavia erecta etc.) if these herbicides are used repeatedly [16]. Paraquat dichloride (1,1'dimethyl-4,4'-bipyridinium ion) is a pre-emergence contact herbicide that is used for pre-plant/pre-crop emergence with formular of $\left(\mathrm{C}_{12} \mathrm{H}_{14} \mathrm{Cl}_{2} \mathrm{~N}_{2}\right)$ chemical fallow, post emergence directed, and harvest aid desiccation in most horticultural and agronomic crops. It is used in these various situations to suppress or control grass and broadleaf weeds [17].

\section{Materials and Methods}

Field trial was undertaken during the dry season, from December 2012 to April 2013, in Bakori, Bakori local government, Katsina state, where the land area was $10.2 \times 5.9 \mathrm{~m}$ and the yearly rainfall was $100 \mathrm{~mm}$ from January 2012 to December 2013. The experiment was a randomized complete block design (RCBD) with a split-plot arrangement using two different treaments (herbicides), ParaeForce ${ }^{(\mathrm{R})}$ (Paraquat) and AminForce ${ }^{(\mathrm{R})}$ (2, 4-D Amine SL) were applied as pre-emergence and post-emergence herbicides. The trail occupied an area of $60.18 \mathrm{~m}^{2}(10.2 \mathrm{~m} \times 5.9 \mathrm{~m})$ which was ploughed, harrowed and the plot was divided into (A and $B$ ) experimental site with $0.3 \mathrm{~m}$ irrigation channels. Each rows (A and $B$ ) consisted of 4 blocks of $6.25 \mathrm{~m}^{2}$ in size. Blocks A and $\mathrm{B}$ were arranged in a randomized complete block design (RCBD)(Figure 1) [13].

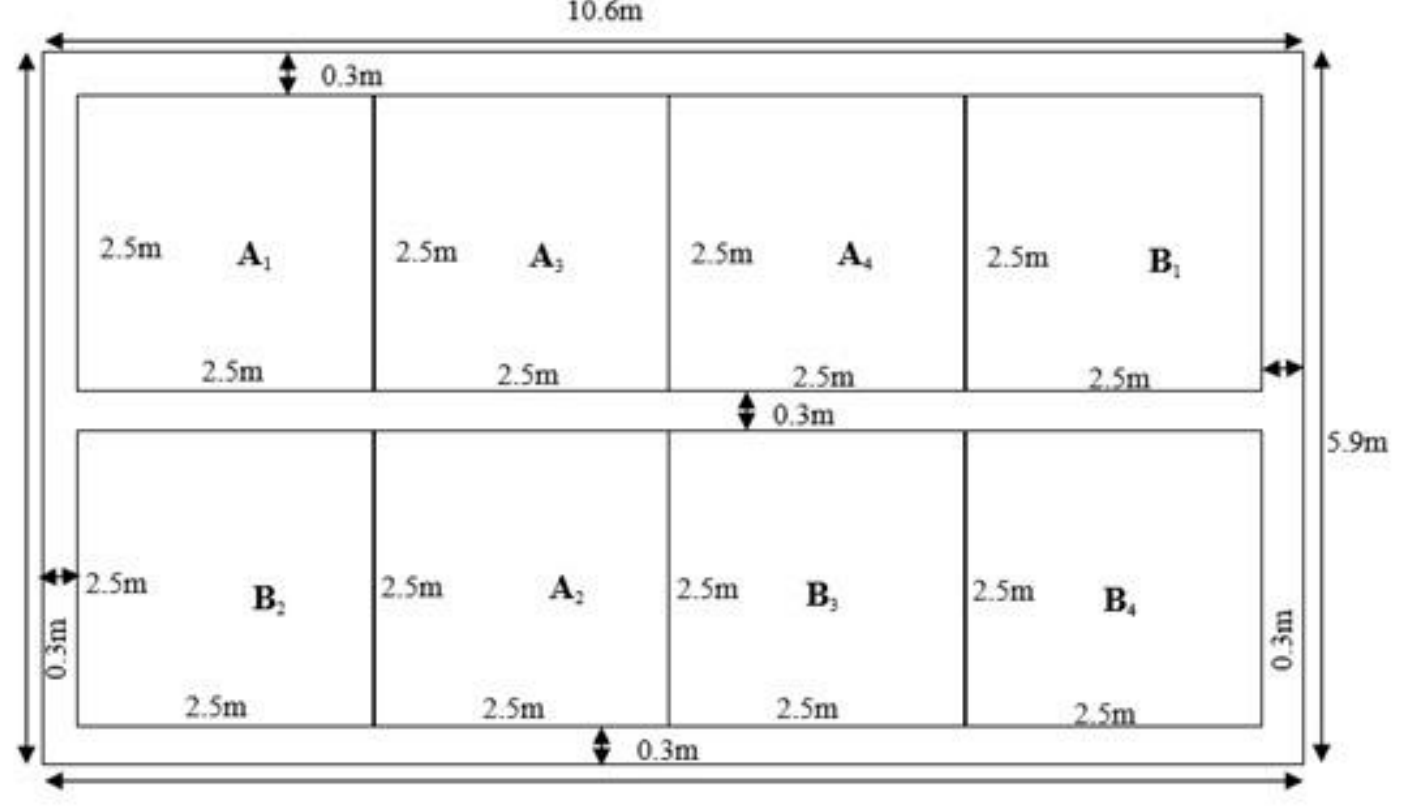

Figure 1: Complete randomized blocks design displaying the plot design.

Blocks $\left(A_{1}\right.$ and $\left.B_{2}\right)$ were considered as control blocks in which no herbicides was applied, while blocks $\left(\mathrm{A}_{3}, \mathrm{~A}_{4}\right.$ and $\left.\mathrm{B}_{1}\right)$ received ParaeForce $^{(\mathrm{R})}$ at $150 \mathrm{~mL} / 20 \mathrm{~L}$ and $\left(\mathrm{A}_{2}, \mathrm{~B}_{3}\right.$ and $\left.\mathrm{B}_{4}\right)$ recieved ParaeForce $^{(\mathrm{R})}$ at $200 \mathrm{~mL} / 20 \mathrm{~L}$ as a pre-emergence herbicide. While AminoForce ${ }^{(\mathrm{R})}$ at $100 \mathrm{ml} / 15 \mathrm{~L}$ was applied to $\left(\mathrm{A}_{3}, \mathrm{~A}_{4}\right.$ and
$\left.\mathrm{B}_{1}\right)$ and AminoForce ${ }^{(\mathrm{R})}$ at $125 \mathrm{~mL} / 15 \mathrm{~L}\left(\mathrm{~A}_{2}, \mathrm{~B}_{3}\right.$ and $\left.\mathrm{B}_{4}\right)$ were applied as post-emergence herbicide at 4 weeks after sowing respectively. Herbicides mixture were prepared by measuring ParaeForce $^{(\mathrm{R})}$ at two different concentrations $150 \mathrm{ml}$ and $200 \mathrm{~mL}$ and mixed with 20liters of water each, $(150 \mathrm{~mL} / 20 \mathrm{~L}$ and 
$200 \mathrm{~mL} / 20 \mathrm{~L})$. Similarly, AminoForce ${ }^{(\mathrm{R})}$ was prepared at two different concentrations of $100 \mathrm{~mL}$ and $125 \mathrm{~mL}$ with 15 liters of water each making concentrations of $100 \mathrm{~mL} / 15 \mathrm{~L}$ and $125 \mathrm{~mL} / 15 \mathrm{~L}$ respectively. Premilary surveys, was carried out during the rainy season from May to October of 2012 and samples of weed species were collected and taken to Herbarium of Biological Science Department of Usmanu Danfodiyo University, Sokoto for identification. Total number of weeds present in each blocks was counted and recorded at 4, 8 and $16 \mathrm{WAS}$ were used to record fresh and dry weight of weeds at 4 , 8 and 16WAS respectively. The fresh wieght of weed species was recorded using electronic weighing balance and the weed species used for fresh weight determination were also use to determine dry weight after oven drying at $120{ }^{\circ} \mathrm{C}$ for 2 hours [3].

Weed index, the reduction in the yield due to the presence of weeds in comparison with weed-free check was calculated using the following formula of Gill, (1996).

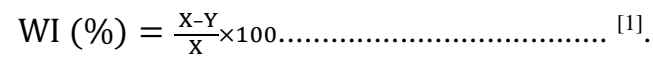

Where:

$\mathbf{X}=$ Maize yield from control plot

$\mathbf{Y}=$ Maize yield of the treated plot

The plant height was measured from base of the plant to the highest open leaf as reported by [18] at 4,8 and 16WAS respectively. The ears of five randomly selected plants from the net plot area at the time of harvest were used to record the observations on yield components. Grain number per cob was calculated from the grain weight per cob and the corresponding 100-grain weight as follows [19].

Grain number per cob $=\frac{\text { Grain weight per cob }(\mathrm{g})}{\text { Weight of } 100 \text { grains }(\mathrm{g})} 100$ ${ }^{[19]}$.
The seeds from sun-dried cobs of five randomly selected plants were separated and weighed. The average weight was recorded as grain weight per cob (g). Hundred maize grains were randomly collected from the net plot yield of each treatment and weighed and expressed in grams. Maize population count was taking at 4, 8 and 16WAS at each block respectively. Data collected were subjected to analysis of variance (ANOVA) using SPSS Statistical Software version 17 and mean were separated by using Least Significant Difference (LSD).

\section{Results and discussion}

A total of 17 weeds species belongs to 11 families (Table 1), family Poaceae and Malveceae had the highest number of species with 6 and 2 species respectively. Weeds like Commelina nudiflora, Cyperus rotundus, Eleusine indica, Doctylocterium aegyptium, Amaranthus spinosus, Cynodon dactylon, Senna occidentalis and Gisekia pharnociode were resistant to ParaeForce(R) at $150 \mathrm{~mL} / 20 \mathrm{~L}$ and $200 \mathrm{~mL} / 20 \mathrm{~L}$ in the first four weeks (4WAS), Cyperus rotundus had high resistance to herbicides used followed by Doctylocterium aegyptium, Cynodon dactylon, Eleusine indica that also resist the herbicides but not as Cyperus rotundus. Similarly, Commelina nudiflora, Cyperus rotundus and Cynodon dactylon were resistant to AminoForce(R) at $100 \mathrm{~mL} / 15 \mathrm{~L}$ and $125 \mathrm{~mL} / 15 \mathrm{~L}$ with high number of weeds count in each blocks followed by Eleusine indica, Amaranthus spinosus and Gisekia pharnociode with the lowest number of weed count at 8 and 16WAS. Cyperus rotundus, Cynodon dactylon, Commelina nudiflora and Doctylocterium aegyptium had survive up to 16WAS. This study further reaffirm the dominance of grasses, sedges and a few broadleaves weeds in the guinea savanna region of Nigeria as reported earlier. The dominance of grasses may be influenced by the large number of seeds they produced that are easily dispersed by wind. Similarly [20] reported that reduction in weed species was possible due to herbicide application in Maize.

Table 1: Weed species encountered in the study area.

\begin{tabular}{|c|c|c|}
\hline Family & Species & English/Common Name \\
\hline Amaranthaceae & Amaranthus spinosus $L$. & Thorny Pigweed \\
\hline Caesalpiniodeae & Senna occidentalis $L$. & Coffee Senna \\
\hline Commelinaceae & Commelina nudiflora $L$. & Spiderwort \\
\hline Convolvulaceae & Ipomoea vagans Bak. & Stork henna \\
\hline Cyperaceae & Cyperus rotundus $L$. & Nut-grass, Nut-sedge \\
\hline Euphorbiaceae & Euphorbia hirta L. & Garden spurge, Snakeweed. \\
\hline Malvaceae & Sida acuta Burm. & Broom weed \\
\hline “ & Sida ovata $L$. & - \\
\hline Molluginaceae & Gisekia pharnociode L. & Oldmaid, gisekia. \\
\hline Papilionoideae & Crotalaria retusa $L$. & Rattlebox, Goats groundnut. \\
\hline Poaceae & Cynodon dactylon $L$. & Bermuda grass, Dog-grass \\
\hline “ & Digitaria gayana Kunth. & Purple-topped finger grass \\
\hline “ & Doctylocterium aegyptium $L$. & Crowfoot-grass \\
\hline “ & Eleusine indica $L$. & Bullgrass, Goose grass \\
\hline “ & Pennisetum pedicellatum Trin. & Kyasuma grass \\
\hline “ & Rottboelia exaltata $L$. & - \\
\hline Solanaceae & Solanum americanum $L$. & Black nightshade \\
\hline
\end{tabular}


Weeds population at 4, 8 and 16WAS was presented in Table 2 . The result revealed that weeds population were significantly $(\mathrm{P} \geq 0.05)$ influenced by sequential application of the herbicides on weed control treatments. At eight weeks after sowing (8WAS) the weedy check had the highest number with 112.5 then 40 after application of ParaeForce ${ }^{(\mathrm{R})}$ and AminoForce ${ }^{(\mathrm{R})}$ at $200 \mathrm{ml} / 20 \mathrm{~L}$ followed by $125 \mathrm{~mL} / 15 \mathrm{~L}$ and 31.67 at $150 \mathrm{ml} / 20 \mathrm{~L}$ followed by $100 \mathrm{~mL} / 15 \mathrm{~L}$; At four weeks after sowing (4WAS) weedy check had the highest number of weeds 73.50 then 29 after applying ParaeForce $^{(\mathrm{R})}$ and AminoForce ${ }^{(\mathrm{R})}$ at $150 \mathrm{~mL} / 20 \mathrm{~L}$ and $100 \mathrm{ml} /$ $15 \mathrm{~L}$ and 13.33 at $200 \mathrm{ml} / 20 \mathrm{~L}$ followed by $125 \mathrm{~mL} / 15 \mathrm{~L}$. At 16WAS the weed count was very low as compared with the other weeks with weedy check of 34 number of weeds, while 7.67 after applying herbicides (ParaeForce ${ }^{(\mathrm{R})}$ fallowed by AminoForce ${ }^{(\mathrm{R})}$ ) at $150 \mathrm{~mL} / 20 \mathrm{~L}$ followed by $100 \mathrm{~mL} / 15 \mathrm{~L}$ and 6 which was treated with herbicides $\left(\right.$ ParaeForce ${ }^{(\mathrm{R})}$ followed by AminoForce ${ }^{(\mathrm{R})}$ ) at $200 \mathrm{~mL} / 20 \mathrm{~L}$ followed by $125 \mathrm{ml} / 15 \mathrm{~L}$. [21] reported that application of ParaeForce ${ }^{(\mathrm{R})}$ injured the weed seeds and can eventually lead to under development of the next generation. In all the stage of maize growth application of herbicides controlled weeds. This is because in comparison with the weedy check the weeds germinated and overcrowd the whole place thereby causing serious competition among the maize and weeds.

Table 2: Total weed count after sequential application of herbicide doses.

\begin{tabular}{cccc}
\hline \multicolumn{4}{c}{ Mean weed count (weeks) } \\
\hline Treatment & Four & Eight & Sixteen \\
\hline $150 \mathrm{ml} / 20$ L fallowed by $100 \mathrm{ml} / 15 \mathrm{~L}$ & $29.00^{a b} \pm 0.58$ & $31.67^{a} \pm 0.88$ & $7.67^{a} \pm 1.20$ \\
$200 \mathrm{ml} / 20 \mathrm{~L}$ fallowed by $125 \mathrm{ml} / 15 \mathrm{~L}$ & $13.33^{a} \pm 1.86$ & $40.00^{a} \pm 3.00$ & $6.00^{a} \pm 1.16$ \\
Weedy check & $73.50^{b} \pm 32.50$ & $112^{b} \pm 7.50$ & $34.00^{b} \pm 7.00$ \\
\hline
\end{tabular}

***mean in the same column followed by similar alphabets are significantly the same using Turkey HSD $(P \geq 0.05), S E=$ Standard error, ml= milliliters and $L=$ Liters

Maize count indicate the number of maize that survived at each stage in each blocks (Table 3), at four weeks after sowing (4WAS) the weedy check had (44) of maize plant then followed by (41.33) after applying (A) ParaeForce ${ }^{(\mathrm{R})}(150 \mathrm{~mL} / 20 \mathrm{~L})$ and also (36.67) at (A) ParaeForce ${ }^{(\mathrm{R})} 200 \mathrm{ml} / 20 \mathrm{~L}$. At eight weeks after sowing (8WAS) it showed that weedy check had (38.00) of maize count followed by (35.00) after sowing (A) ParaeForce ${ }^{(\mathrm{R})}$ followed by (B) AminoForce ${ }^{(\mathrm{R})}$ at $150 \mathrm{ml} / 20 \mathrm{~L}$ followed by $100 \mathrm{~mL} / 15 \mathrm{~L} \mathrm{block}^{-1}$ and 30.00 with (A) ParaeForce ${ }^{(\mathrm{R})}$ followed by (B) AminoForce ${ }^{(\mathrm{R})}$ at $200 \mathrm{ml} / 20 \mathrm{~L}$ followed by $125 \mathrm{~mL} / 15 \mathrm{~L}$ block $^{-1}$, Also at $16 \mathrm{WAS}$ weedy check had the highest number of maize (36.50) followed by (32.33) in (A) ParaeForce ${ }^{(\mathrm{R})}$ followed by (B) AminoForce ${ }^{(\mathrm{R})}$ at $150 \mathrm{ml} / 20 \mathrm{~L}$ followed by $100 \mathrm{ml} / 15 \mathrm{~L}$ block $^{-1}$ and 22.00 numbers of maize plants in (A) ParaeForce ${ }^{(\mathrm{R})}$ followed by (B) AminoForce ${ }^{(R)}$ at $200 \mathrm{~mL} / 20 \mathrm{~L}$ followed by $125 \mathrm{~mL} / 15 \mathrm{~L} \mathrm{block}^{-1}$ respectively. Maize count at the initial stage did not germinate which may be due to some natural factors such as herbicide concentration, birds and insects. However in the later stage of maize development sign of herbicidal injuries were observed which may be due to errors during application. Application of herbicides can regulate maize growth by stopping the photosynthetic activities of the maize [22, 23].

Table 3: Effect of sequential Application of Herbicide Doses on Maize Count.

\begin{tabular}{cccc}
\hline \multicolumn{4}{c}{ Mean Maize \pm SE per weeks } \\
\hline Treatment & Four & Eight & Sixteen \\
\hline 150ml/20L fallowed by 100ml/15L & $41.33 \pm 3.53$ & $35.00 \pm 2.87$ & $32.33 \pm 3.53$ \\
200ml/20L fallowed by $125 \mathrm{ml} / 15 \mathrm{~L}$ & $36.67 \pm 1.33$ & $30.00 \pm 0.88$ & $22.00 \pm 4.04$ \\
Weedy check & $44.00 \pm 2.00$ & $38.00 \pm 1.11$ & $36.50 \pm 0.50$ \\
\hline
\end{tabular}

The plant height at four weeks after sowing (4WAS), eight week after sowing (8WAS) and at harvest (16WAS) was significantly $(\mathrm{P} \geq 0.05)$ influenced by weed control (Table 4$)$. The control treatments showed significant effect on plant height at all stages of maize growth. At four weeks after sowing (4WAS) weedy check had the lowest value of $0.16 \mathrm{~m}$ while treatment blocks had $0.24 \mathrm{~m}, 0.22 \mathrm{~m}$, eight weeks after sowing (8WAS) had weedy check with highest value of $(1.50 \mathrm{~m})$ and treatment blocks of
$(0.55 \mathrm{~m}, 0.58 \mathrm{~m})$ respectively. At harvest (16WAS) treatment blocks had $(2.71 \mathrm{~m}, 1.93 \mathrm{~m})$ while weedy check had $(2.50 \mathrm{~m})$. The application of herbicides affected maize plant height which may be due to the contact with the AminoForce ${ }^{(\mathrm{R})}$ which is a growth regulator [24]. It was observed that the initial stage application of ParaeForce ${ }^{(\mathrm{R})}$ controlled population which makes a good start for the maize as there was no any competition with the weed.

Table 4: Effect of sequential Application of Herbicide on Maize Plant Height.

\begin{tabular}{cccc}
\hline \multicolumn{4}{c}{ Mean Plant Height $(\boldsymbol{m}) \pm$ SE per weeks } \\
\hline Treatment & Four & Eight & Sixteen \\
\hline 150ml/20L fallowed by $100 \mathrm{ml} / 15 \mathrm{~L}$ & $0.24^{b} \pm 0.01$ & $0.55^{a} \pm 0.03$ & $2.71 \pm 0.35$ \\
200ml/20L fallowed by $125 \mathrm{ml} / 15 \mathrm{~L}$ & $0.22^{b} \pm 0.02$ & $0.58^{b} \pm 0.09$ & $1.93 \pm 0.19$ \\
Weedy check & $0.16^{a} \pm 0.01$ & $1.50^{a} \pm 1.11$ & $2.50 \pm 0.05$ \\
\hline
\end{tabular}


Weed index differed significantly $(\mathrm{P} \geq 0.05)$ due to various weed control treatments in (Table 5). Weedy check had the lowest value of 0.00 and $36.07 \%$ at $150 \mathrm{ml} / 20 \mathrm{~L}$ followed by $100 \mathrm{ml} /$ $15 \mathrm{~L}$, while $37.71 \%$ at $200 \mathrm{ml} / 20 \mathrm{~L}$ followed by $125 \mathrm{ml} / 15 \mathrm{~L}$ respectively. Number of grain per cob differed significantly due to various weed control treatments (Table 5). Weedy check had the lowest value of 270.21 then 282.53 at $150 \mathrm{ml} / 20 \mathrm{~L}$ followed by $100 \mathrm{ml} / 15 \mathrm{~L}$, while 302.83 at $200 \mathrm{~mL} / 20 \mathrm{~L}$ followed by $125 \mathrm{ml}$ $/ 15 \mathrm{~L}$ respectively. Weed index which is the reduction in the yield due to the presence of weeds in comparison with weed free check. In both the 2 different herbicides application weeds index value as compared to weedy check had significantly $(\geq 0.05)$ which is due to the herbicides application on them. Grain number per cob shows that sequential application of herbicide at all the different concentration contributed to the yield of maize as compared to weedy check which had low number of seeds. This was due to the low competition as compared to the weedy check $[25,26,27]$.

Table 5: Effect of sequential Application of Herbicide Doses on Weed index (WI) and Grain Number per Cob (GNPC).

\begin{tabular}{ccc}
\hline \multicolumn{3}{c}{ Mean of WI and GNPC \pm SE } \\
\hline Treatment & WI\% & GNPC \\
\hline 150ml/20L followed by $100 \mathrm{ml} / 15 \mathrm{~L}$ & $36.07 \pm 26.65$ & $282.53 \pm 25.39$ \\
$200 \mathrm{ml} / 20$ L followed by $125 \mathrm{ml} / 15 \mathrm{~L}$ & $37.71 \pm 23.03$ & $302.83 \pm 12.88$ \\
Weedy check & $0.00 \pm 0.00$ & $270.21 \pm 47.99$ \\
\hline
\end{tabular}

\section{Conclusion}

For every farmer in North-Western Nigeria. Identifying the types of weeds in your farm land is one of the most important factors influencing the effectiveness of weeds control using herbicides. Therefore, sequential application of herbicides (ParaeForce(R) and AminoForce( $\mathrm{R})$ ) at time intervals had reduce the tendency of weeds resistance and improve growth and yield of maize, herbicides formulation of $200 \mathrm{ml} / 20 \mathrm{~L}$ followed by $125 \mathrm{ml} / 15 \mathrm{~L}$ which shows positive response were highly recommended.

\section{Authors contribution}

BSH and NW conducted the research, MDA drafted the manuscripts, SWH formatted and English checking and BLA design and supervised the research.

\section{Conflict of interests}

None.

\section{Acknowledgements.}

The author wishes to acknowledge the farmers for sharing their valuable knowledge with us.

\section{References}

1. McMahon, M.J., A.M. Kofranek and V.E. Rubatzky, Hartmann's plant science. New Jersey, United States of America: Prentice Hall, (2002).

2. Khandaker, M.M., U.A. Abdullahi, M.D. Abdulrahman, N.A. Badaluddin and K.S. Mohd, Bio-ethanol production from fruit and vegetable waste by using saccharomyces cerevisiae, in Bioethanol. (2020). IntechOpen.

3. Magani, I., Effect of period of weed interference and season-long weed control in maize (Zea mays L.) M. Sc. (1990), Thesis, Ahmadu Bello University, Samaru-Zaria.

4. Williams, O. and S. Lagoke, Incidence of Weed Flora Composition in Maize (Zea mays L.) Intercropped with Cover Crops under Three Weed Control Methods at Alabata, Southwest, Nigeria. International Journal of Innovative Science and Research Technology. (2018). 3 (12) p. 295-305.

5. Liebman, M., B. Baraibar, Y. Buckley, D. Childs, S. Christensen, R. Cousens, H. Eizenberg, S. Heijting, D. Loddo and A. Merotto Jr, Ecologically sustainable weed management: how do we get from proof-of-concept to adoption? Ecological Applications. (2016). 26(5): p.1352-1369.

6. Adekpe, D., L. Aliyu, J. Shebayan, D. Ishaya and T. Peter, Economic analysis of chemical weed control in irrigated garlic (Allium sativum L.) in Sudan Savanna Ecology, Nigeria. Crop Protecttion. (2007). 26(12): p. 1790-1793.
7. Rodenburg, J. and D. Johnson, Weed management in rice-based cropping systems in Africa. Advances in agronomy. (2009). 103: p. 149-218.

8. Beckie, H.J., Herbicide-resistant weeds: management tactics and practices. Weed Technology., (2006). 20(3): p. 793-814.

9. Bàrberi, P., Weed management in organic agriculture: are we addressing the right issues? Weed Resistance. (2002). 42(3): p. 177-193.

10. De Villiers, E.J.D., The competitive advantage of velvet beans as an economic agricultural commodity. 2015.

11. Sharrow, S.H., Silvopastoralism: competition and facilitation between trees, livestock, and improved grass-clover pastures on temperate rainfed lands. Agroforestry in sustainable agricultural systems, Lewis Publications., NY, USA.(1999).

12. Rana, S.S. and M. Rana, Principles and practices of weed management. Department of Agronomy, College of Agriculture, CSK Himachal Pradesh Krishi Vishvavidyalaya, Palampur, (2016). p. 138.

13. Dalorima, T.L., A.J. Zakaria, A. Majrashi, K. Mahmud, K.S. Mohd, H. Muhammad and M.M. Khandaker, Impacts of vermicomposting rates on growth, yield and qualities of red seedless watermelon. Australian Journal of Crop Science. (2018). 12(11): p. 1765-1773

14. Sandhu, K., S. Mehra and H. Gill, Studies on weed control in winter maize through herbicides. Journal Research Punjab Agriculture University. (1996). 23(4): p. 549556.

15. Pandey, A., P. Singh, V. Prakash, R. Singh and V. Chauhan, Direct and Residual effect of weed control measures in Maize (Zea mays) and Wheat (Triticum aestivum) cropping system under Mid-Hill conditions of NW Himalayas. Indian Journal of Weed Science. (1999). 31(3and4): p. 204-209.

16. Adigun, J., Critical period of weed interference in rainfed and irrigated tomatoes in the Nigerian savanna. Agricultura tropica et subtropica. (2005). 38(2): p. 73-80.

17. Hamill, A.S., Minutes of the Board of Directors Meeting Weed Science Society of America. Weed Science.(1990). 38(6): p. 649-654

18. Culliney, T.W., Benefits of classical biological control for managing invasive plants. Crit. Rev. Plant Science.(2005). 24(2): p. 131-150.

19. Takim, F.O. and O. Fadayomi, Influence of Tillage and Cropping Systems on Field Emergence, Growth of Weeds and Yield of Maize ('Zea mays'L.) and Cowpea ('Vigna unguiculata L.). Australian Journal of Agricultural Engineering. (2010). 1(4): p. 141148.

20. Imoloame, E., Evaluation of herbicide mixtures and manual weed control method in maize (Zea mays L.) production in the Southern Guinea agro-ecology of Nigeria Cogent Food \& Agriculture. (2017). 3(1): p. 1375378.

21. Olorunmaiye, P.M. and K.S. Olorunmaiye, Effect of integrated weed management on weed control and yield components of maize and cassava intercrop in a southern Guinea savanna ecology of Nigeria. Australian Journal of Crop Science. (2009). 3(3): p. 129. 
22. Adigun, J., T. Lagoke and I. Adekpe, Efficacy of selected herbicides for weed control in rain-fed upland rice in the Nigerian Northern Guidea Savanna. Agricultura Tropica et Subtropica. (2005). 38(3-4): p. 99-106.

23. Hamad, S. W. Bioherbicidal properties of sunflower (Helianthus annuиs L.) and its activities in weed management. Thesis. Newcastle University. (2017).

24. Umar, U., M. Abdulrahman and S. Abdullahi, Assessment of genetic variability of maize inbred lines and their hybrids under normal and drought conditions. Nigeria Agricultural Journal. (2016). 46(2): p. 82-88.

25. Peer, F., B. Hassan, B. Lone, S. Qayoom, L. Ahmad, B. Kh, P. Ssingh and G. Singh, Effect of weed control methods on yield and yield attributes of soybean. African Journal of Agricultural Research. (2013). 8(48): p. 6135-6141.

26. Khandaker, M.M., A. Fatini, M.D. Abdulrahman, U.A. Abdullahi and N.A. Badaluddin, Growing Media Influence on the Growth and Development of Rosa Hybri. Plant Archives. (2020).20(2). p. 6001-6009.

27. Hamad, S. W. Bioherbicidal Actions of Common Purslane on Seed Germination and Growth of Some Crop and Weed Species.IOP Conference Series: Earth and Environmental Science. (2021). IOP Publishing.910 (1). 